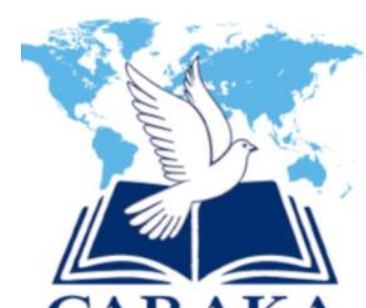

\title{
Karakteristik Gembala Wanita Bagi Pertumbuhan Gereja Secara Kualitas Di GBI Gloria Tikalong Kecamatan Mempawah Hulu Kabupaten Landak
}

\author{
Pustikawaty Djunaidi, Yusak Setianto, Robert Paul Trisna \\ Sekolah Tinggi Teologi Bethel Indonesia \\ Pdt.wati@gmail.com \\ afui_yusak@yahoo.co.id \\ roberttrisna@sttbi.ac.id
}

\begin{abstract}
The role of women in church life has always been a discussion that invites new understanding. Starting from whether or not a woman is allowed to lead, to what impact women have on the organizational life of the church and the growth of the congregation's faith. However, to achieve this goal, it is necessary to have the capacity and criteria that are owned. This study aims to determine how the characteristics of female pastors for church growth in quality and quantity at the Gloria Tikalong Indonesian Bethel Church Mempawah Hulu, Landak district, West Kalimantan. Qualitative methods were used to express field data descriptively by collecting observation and interview data. The results of the study indicate that the characteristics of pastors for church growth are as follows: Effective leadership, leader's vision, being an example in word and deed, serving and not being served. In addition, there are also characteristics of a mother's instinct, the power of prayer and self-sacrifice which are characteristics of an effective female leader. While the impact resulting from the characteristics of the female pastor is the congregation is experiencing growth in quality and quantity.
\end{abstract}

Keywords: Characteristics; Shepherd; growth; quantity; quality

\begin{abstract}
Abstrak
Peran wanita dalam kehidupan bergereja selalu menjadi diskusi yang mengundang pemahaman baru. Dimulai dari diperbolehkan atau tidaknya seorang wanita memimpin, hingga dampak apa yang diberikan wanita dalam kehidupan berorganisasi gereja dan pertumbuhan keimanan jemaat. Hanya saja, untuk mencapai kepada tujuan tersebut, perlu adanya kapasitas dan kriteria yang dimiliki. Penelitian ini bertujuan untuk mengetahui bagaimana karakteristik gembala wanita bagi pertumbuhan gereja secara kualitas dan kuantitas di Gereja Bethel Indonesia Gloria Tikalong Mempawah Hulu, kabupaten Landak Kalimantan Barat. Metode kualitatif digunakan untuk mengungkapkan data lapangan secara deskriptif dengan pengumpulan data observasi dan wawancara. Hasil penelitian menunjukkan bahwa karakteristik gembala bagi pertumbuhan gereja secara kualitas sebagai berikut: Kepemimpinan yang efektif, visi pemimpin, menjadi teladan dalam perkataan dan perbuatan,
\end{abstract}


melayani dan bukan dilayani. Selain itu, terdapat juga karakteristik naluri seorang ibu, kuasa doa dan rela berkorban yang menjadi karakteristik pemimpin wanita yang efektif. Sedangkan dampak yang dihasilkan dari karakteristik gembala wanita adalah jemaat mengalami pertumbuhan secara kualitas dan kuantitas.

Kata Kunci: Karakteristik; Gembala wanita; pertumbuhan; kuantitas; kualitas

\section{PENDAHULUAN}

Pelaksanaan tugas pokok seorang gembala secara eksplisit dijelaskan dalam Yehezkiel 34:11-16. Karakteristik seorang gembala tersebut akan membawa kepada pertumbuhan gereja secara kualitas yaitu dengan meneladani Yesus Kristus sebagai Gembala Agung orang percaya. Gembala yang meneladani Yesus dalam Yehezkiel 34:11-16 terlihat progres dari tindakan Tuhan dalam menggembalakan umat-Nya: Pertama, seorang gembala akan memperhatikan secara menyeluruh kebutuhan domba gembalaannya, termasuk kebutuhan fisik. Kedua, seorang gembala akan pergi mencari domba yang keluar dari kawanan untuk dibawa kembali kepada kawanan. Ketiga, Tuhan akan mengumpulkan mereka kembali di tanah perjanjian. Kelima Tuhan sendiri yang akan menggembalakan mereka dengan memberikan tempat peristirahatan dan makanan yang sehat bagi domba-domba-Nya. ${ }^{1}$

Karakteristik menjadi gembala yang baik juga terlihat dalam 1 Petrus 5:2-3 yang menjelaskan bagaimana seorang gembala mesti memiliki karakteristik sukarela, rendah hati, melakukan pelayanan dengan pengabdian kepada Allah, dan mampu menjadi teladan yang baik bagi domba kawanannya. ${ }^{2}$ Kembali bahwa karakteristik tersebut telah Yesus lakukan terlebih dahulu. Yesus digambarkan sebagai seorang gembala yang datang untuk menyelamatkan dombanya. Domba yang dimaksud adalah manusia yang sedang dalam jalan menuju kebinasaan. Yesus datang untuk membawa manusia itu kepada jalan kebenaran dan memperoleh hidup yang kekal. ${ }^{3}$ Tugas ini selanjutnya diberikan kepada para gembala yang Tuhan berikan tanggung jawab untuk menjaga domba-domba-Nya. Para gembala dipanggil dan mayoritas dikerjakan oleh pria karena dianggap sanggup untuk menjalankan tugas besar ini. Lalu bagaimana tugas penggembalaan ini dialihkan atau dikerjakan oleh seorang wanita?

Berkaca kepada Firman Tuhan dalam Kejadian 1:27, pada dasarnya pria dan wanita diciptakan dengan keunikan masing-masing. Baik pria dan wanita tidak hanya diberikan kewajiban saja, namun juga hak, kedudukan dan peran yang tidak dibedakan. Sebagai makhluk, pria dan wanita masing-masing memiliki keterbatasan dan kelebihan digunakan

\footnotetext{
${ }^{1}$ Bigman Sirait, Tabloid Reformata, Ed 190 (Jakarta: Yayasan pelayanan Media Antiokia, 2015), 9.

${ }^{2}$ Calvin Sholla Rupa, "Ciri Khas Seorang Gembala Berdasarkan Perspektif 1 Petrus 5:1-4," Jurnal Jaffray 14, no. 2 (2016): 165.

${ }^{3}$ K. Thomas Resane, "Leadership for the Church: The Shepherd Model," HTS Teologiese Studies / Theological Studies 70, no. 1 (2014), 2.
}

189 | Copyright $@$ 2021, CARAKA, ISSN 2722-1407 (Cetak), 2722-1393 (Online) 
untuk saling melengkapi. Demikianlah seharusnya hubungan antara pria dan wanita pujian dan nabiah yang sangat ideal. Stedman menegaskan bahwa manusia diciptakan dalam "gambar " dan "rupa" Allah, gambar itu tidak hanya ditemukan dalam tubuh atau jiwa manusia, tetapi juga dalam roh manusia. Jika roh manusia diciptakan segambar dengan Allah, maka roh manusia sama dengan Roh Allah, apa yang dapat dilakukan oleh Roh Allah maka roh manusia juga dapat melakukan berbagai hal yang dapat dilakukan oleh Allah (Yoh. 14:12). Pada bagian ini, Stedman menyatakan, wanita diciptakan untuk menjadi penolong bagi laki-laki yang sesuai dan sepadan dengannya, dan pendamping untuk melengkapi dan menyempurnakannya. ${ }^{4}$

Jelas bahwa wanita pada hakikatnya dapat memimpin dan menggembalakan jemaat yang Tuhan percayakan. Layaknya wanita dapat berperan dalam kancah kebangsaan, maka dalam konteks penggembalaan fakta ini dapat diterapkan. ${ }^{5}$ Alkitab banyak menceritakan wanita hebat yang dapat menginspirasi bangsanya. Mulai dari Ester yang berani, sabar, dan rela berkorban. Selanjutnya Maria yang patuh dan berkorban demi menjaga Yesus. ${ }^{6}$ Fakta ini mengharuskan setiap orang percaya menerima kenyataan bahwa wanita dapat memimpin dengan integritas dan ciri khasnya sendiri. ${ }^{7}$ Khususnya dalam pertumbuhan jemaat ke arah kuantitas dan kualitas. Bagaimana pemimpin wanita dapat membawa jemaat ke arah integritas hidup. Integritas didefinisikan sebagai suatu keadaan menjadi lengkap, menyatu. Jikalau peneliti mempunyai integritas maka kata-katanya sesuai perbuatannya. Maxwell juga menegaskan seorang yang berintegritas loyalnya tak terpecah, sikapnya tidak mendua, atau mempunyai sikap yang berpura-pura. ${ }^{8}$ Tujuan nilai hidup ini dapat dikerjakan oleh wanita dalam lingkup gereja.

Menurut Bangun, persoalan etika dapat meledak sewaktu-waktu dalam upaya pembuatan keputusan. Sikap etis seseorang berakar di dalam standar kejujuran dan keadilan. Apa yang dipercaya orang sebagai jujur dan adil ditentukan oleh keputusan dan bagaimana keputusan itu diambil. Oleh karena itu, amat penting memahami arti dari integritas supaya integritas menjadi landasan operasional seseorang membuat keputusan. ${ }^{9}$ Karakteristik pemimpin wanita yang sesuai Firman Tuhan adalah yang berintegritas. ${ }^{10}$ Berintegritas adalah

\footnotetext{
${ }^{4}$ Ray. C.Stedmen, Petualangan Menjelajah Perjanjian Lama (Jakarta: Duta Harapan Dunia, 2014), 74.

${ }^{5}$ Ivonne Sandra Sumual, "Potret Perempuan Gereja Dalam Berbangsa," in Bergereja Dalam Bingkai Kebangsaan (Jakarta: STT Bethel Indonesia, 2016), 121.

${ }^{6}$ Andi Yohanes, Tegarnya Iman Wanita (Jakarta: ANDI Offised, 2005), 94.

${ }^{7}$ Gernaida Krisna R. Pakpahan, "Perempuan Dan Kerajaan Allah," in Reaffirming Our Identity: Isu-Isu Terpilih Menjawab Perubahan Sekaligus Mempertahankan Identitas, ed. Junifrius Gultom and Frans Pantan (Jakarta: Bethel Press, 2014), 105-109.

${ }^{8}$ Maulana Mukhlis and Idil Akbar, "Strengthening the Integrity of Local Leadership and Its Relevance to Run Democratic Governance," FIAT JUSTISIA:Jurnal Ilmu Hukum 11, no. 2 (2018): 109.

${ }^{9}$ Departement Wanita Bethel Indonesia, "Modul Wanita Cakap Berdampak" (Jakarta: Gereja Bethel Indonesia, 2017).

${ }^{10}$ Yosafat B, Integritas Pemimpin Pastoral (Yogyakarta: ANDI Offised, 2010), 34.
} 
wanita yang memiliki pikiran yang cerdas, utuh dan wawasan yang luas, emosi yang dapat dikelola dengan baik (dewasa emosi), tujuan hidup yang benar dan teguh, memiliki daya tahan dan daya juang yang kuat, mampu berbagi hidup dengan orang lain, mentaati peraturan yang ada, fokus pada nilai-nilai yang ada pada firman Tuhan. ${ }^{11}$

Integritas pribadi akan nampak dalam hidup seseorang dalam berbagai bentuk menurut Wagner dalam memotret seorang pemimpin gembala di gereja yaitu; Pertama, kejujuran (Mat. 5:37) dimana manusia di zaman akhir ini cenderung suka berdusta, roh pendusta mendorong manusia untuk membuat begitu banyak bentuk kebohongan, dari hal yang kecil dan sepele sampai hal yang besar bahkan berhubungan dengan hidup yang kekal. Kedua, ketulusan, budaya di akhir zaman ini adalah budaya yang anti kebenaran yang mutlak. Kebenaran yang mutlak dianggap kesombongan, fanatik dan arogan. Pudarnya kebenaran yang mutlak menyebabkan kebenaran menjadi relatif dan sangat personal. Hal ini jugalah yang mempengaruhi hidup kekristenan yaitu orang yang percaya Tuhan Yesus dewasa ini. Mereka menyaksikan cinta Tuhan tidak lagi dengan tulus, tidak dengan benar artinya bukan injil Tuhan yang diberitakan tetapi kesaksian-kesaksian pribadi yang lebih menonjolkan diri sendiri yang perlu diuji kebenarannya. Setiap orang percaya Yesus harus menceritakan kebenaran seluruh isi Alkitab, kalau dalam Alkitab tertulis Yesus satu-satunya jalan, kehidupan dan kebenaran maka dimanapun kita berada hal ini harus terus disampaikan tak perlu menutup-nutupi. Orang yang beriman dan berintegritas akan berani mengatakan hal ini dengan terus terang karena mereka mempunyai hati yang cinta Tuhan dengan tulus hati. ${ }^{12}$

Ketiga, keadilan. Hidup dengan menjaga keadilan menunjukkan pada sebuah relasi, hubungan dengan sesama, hubungan yang lengkap, yang mencakup hubungan dengan Allah, manusia dan diri sendiri. Hubungan bukan sekedar secara lahiriah tetapi juga menyangkut nilai-nilai yang diterapkan dalam menjalani hubungan tersebut. Dalam praktis sehari-hari, tindakan ini dapat dilihat dari kehidupan yang saling menghargai dan saling mengakui posisi dan fungsi masing-masing serta menjalankannya dengan penuh tanggungjawab. ${ }^{13}$ Dari hubungan itulah orang lain dapat merasakan dan melihat ada kehidupan bersama yang didasari pada nilai-nilai kebenaran yang mutlak yang berasal dari firman Allah. Gernaida menekankan bahwa keadilan adalah kebenaran praktis yang harus ada dalam seluruh aspek kehidupan manusia, termasuk dalam konteks kerohanian. ${ }^{14}$ Keempat, kemurnian yang berarti

${ }^{11}$ Ivonne Sandra Sumual, "Perempuan Dalam Gerakan Pentakosta," in Reaffirming Our Identity: IsuIsu Terpilih Menjawab Perubahan Sekaligus Mempertahankan Identitas, ed. Junifrius Gultom and Frans Pantan (Jakarta: Bethel Press, 2014), 125-142.

${ }^{12}$ C Peter Wagner, Gereja Saudara Dapat Bertumbuh (Malang: Gandum Mas, 2002), 95.

${ }^{13}$ Gernaida KR. Pakpahan, Jalan Sunyi Kenabian Amos: Perjuangan Menegakkan Keadilan (Jakarta: Hegel Pustaka, 2021), 34-40.

${ }^{14}$ Gernaida K.R. Pakpahan, "Membangun Solidaritas Kemanusiaan: Kritik Nabi Amos Terhadap Praktik Pelanggaran Hak Asasi Manusia,” Manna Rafflesia 7, no. 2 (2021): 441-466. 
tidak tercemar oleh sesuatu yang asing, bebas dari sesuatu yang kotor, dan suci dari hama. Dalam catatan Alkitab, seperti yang tertulis dalam Mazmur 12:7; 18:31; 19:9 menjelaskan bahwa segala janji dan perintah Tuhan adalah murni. Oleh karenanya Paulus menjaga hati nurani yang murni di hadapan Allah dan manusia (Kis. 24:16), demikian dengan Timotius diingatkan oleh guru besarnya yaitu Rasul Paulus dalam 1 Timotius 4:16; 5:22 agar menjaga kemurnian dirinya dan kemurnian pengajaran teologinya. Berintegritas berarti memelihara dan menjaga hati tetap fokus pada Tuhan Yesus dan pimpinan Roh Kudus sehingga bisa mengakibatkan pelayanan kita juga tetap murni. ${ }^{15}$

Kelima, rendah hati. Kerendahan hati adalah ciri khas sifat Tuhan Yesus, berbeda dengan rendah diri dan sombong. Orang yang rendah diri adalah orang yang mempunyai konsep tentang dirinya sendiri yang rendah, mereka cenderung menghina orang lain, tidak menerima keberadaan orang lain, tidak puas dengan diri sendiri serta membandingkan diri dengan orang lain. Sebaliknya orang sombong adalah mereka yang senang membanggakan diri sendiri, memuji diri, meninggikan diri, memberi penilaian diri yang berlebihan, memamerkan diri, meremehkan orang lain dan menempatkan diri lebih tinggi daripada orang lain. Ingat baik-baik Tuhan Yesus tak pernah menginginkan pengikut-Nya rendah diri dan sombong. Rendah hati adalah buah dari suatu proses yang berasal dari Tuhan Yesus dan terus menerus belajar dari Dia. Pengenalan akan Tuhan Yesus menyebabkan seseorang mengenal diri sendiri, pengenalan diri sendiri juga akan menyebabkan seseorang mempunyai konsep tentang diri sendiri yang benar dan utuh. Kerendahan hati selalu didapati melalui sebuah proses yang penuh dengan pergumulan, dan penderitaan. Seperti Tuhan Yesus yang rendah hati, sebagai orang yang percaya juga harus mempunyai salah satu komponen dari integritas tersebut, yakni kerendahan hati. ${ }^{16}$

Keenam, tidak mencari kepentingan diri sendiri atau egoisme. Egoisme adalah karakter seorang yang menghambat pertumbuhan rohani seseorang, terkhusus dari pertumbuhan gereja. Paulus menulis dalam Filipi 2:3 supaya jemaat di Filipi jangan mencari keuntungan diri sendiri atau puji-pujian yang sia-sia. Demikian dalam 2 Korintus 5:22 bagaimana mereka harus hidup dalam kerendahan hati. Orang berintegritas adalah orang bisa memprioritaskan kepentingan yang kekal bagi orang lain daripada kepentingannya sendiri (Yoh. 17:11). Orang percaya juga harus menjaga kesatuan hati antar umat Tuhan dalam kehidupan sehari-hari. Ketujuh, terpercaya. Orang yang terpercaya adalah mereka yang telah teruji dalam perkataan dan tindakan melalui kehidupan sehari-hari. Hal itu telah teruji melalui bermacam-macam tantangan yang terjadi dalam hidup orang tersebut. Orang menjadi terpercaya oleh karena

\footnotetext{
${ }^{15}$ Rupa, 165.

${ }^{16}$ Warren W. Wiersbe, Hidup Bersama Firman-Renungan Harian Pasal Demi Pasal Seluruh Alkitab
} (Jakarta: Renungan Harian, Yayasan Glori, 2012), 175. 
mereka tidak pernah menyalahgunakan otoritas yang didapat kalau orang tersebut mempunyai kedudukan, tidak menyalahgunakan fasilitas untuk kepentingan pribadi. Hal-hal yang seperti itulah yang menyebabkan seseorang dapat dipercaya. ${ }^{17}$ Dari paparan diatas, maka dapat disimpulkan bahwa karakteristik yang mesti dimiliki oleh seorang pemimpin berintegritas adalah orang yang jujur, tulus hati, adil, murni hati, rendah hati, tidak mencari kepentingan diri sendiri dan dapat dipercaya.

Istilah pertumbuhan gereja memiliki pengertian yang luas karena dipengaruhi oleh berbagai faktor yang saling berkaitan. Dalam konteks Alkitab pertumbuhan yang dimaksud oleh peneliti adalah bertambah atau berkembangnya gereja baik secara kualitas maupun secara kuantitas. Lukas dalam Kisah Para Rasul banyak menulis tentang bertambah atau berkembangnya gereja. Kisah Para Rasul 2:24 dicatatkan pertambahan jumlah secara kuantitas menjadi 3000 jiwa. McGavran tokoh pergerakan pertumbuhan gereja, pencetus istilah church growth. Ia menjelaskan bahwa church growth adalah segala sesuatu yang terkait dengan membawa orang-orang yang tidak memiliki hubungan pribadi dengan Yesus Kristus ke dalam persekutuan dengan Dia dan membawa mereka menjadi anggota gereja yang bertanggung jawab adalah pertumbuhan gereja. ${ }^{18}$

Wagner menyatakan alat utama bagi pertumbuhan gereja adalah pemberitaan Injil. Faktor katalis utama dalam pertumbuhan gereja lokal adalah pendetanya, lebih jauh lagi Wagner menyatakan bahwa kepemimpinan yang kuat dalam penggembalaan adalah seorang gembala yang kepemimpinan dinamisnya dapat mempengaruhi. Pertumbuhan gereja harus didasari sebagai tujuan yang ditetapkan oleh Tuhan Yesus, sebagai kepala gereja (Ef. 4:1314). ${ }^{19}$ Menurut Menzies dan Horton tujuan pertumbuhan gereja yaitu untuk memberitakan Injil ke seluruh dunia, sesuai dengan Amanat Agung dalam Injil Matius 28:19-20 dan membangun sekumpulan orang-orang kudus, mengasuh mereka supaya mereka serupa dengan Kristus. Allah sangat memperhatikan jiwa-jiwa yang masih bayi rohani, yang akan bertumbuh dalam kasih karunia. Allah menghendaki orang percaya bertumbuh dan menghasilkan buah Roh (Gal. 5:22-23). ${ }^{20}$

Tanda kedua adalah membebaskan kaum "awam” atau jemaat. Maksud awam dalam konteks ini bukan berarti mereka yang tidak memahami iman Kristen secara mendalam, melainkan mereka yang tidak mengenyam pendidikan teologi untuk diperlengkapi dalam

${ }^{17}$ Peter Wagner, Changing Church: How God Is Leading His Church into The Future (California: Ventura, 2014), 56.

${ }^{18}$ Peter Wagner, Strategi Perkembangan Gereja (Malang: Gandum Mas, 2002), 175.

${ }^{19}$ Yonathan Wiryohadi, "Gereja Berbasis Visi \& Misi Kerajaan Allah," in Reaffirming Our Identity: Isu-Isu Terpilih Menjawab Perubahan Sekaligus Mempertahankan Identitas, ed. Junifrius Gultom and Frans Pantan (Jakarta: Bethel Press, 2014), 250-254.

${ }^{20}$ Ed. Stanley M. Horton., "Systematic Theology, A Pentecostal Perspective.," in The Creation of the Universe and Humankind, by Timothy Munyon (Springfield: Logion Press, 1994), 57. 
pelayanan. Gembala yang gerejanya bertumbuh dan sehat tahu bagaimana mengaktifkan jemaat, memotivasi mereka dalam pelayanan, menciptakan struktur gereja yang melibatkan jemaat menjadi aktif dan produktif. $^{21}$ Dengan kata lain, jemaat terlibat aktif bagi pertumbuhan gereja yang dipimpinnya. Tindakan ini merupakan kehendak Allah bagi gerejaNya seperti yang ada di dalam Alkitab. Allah yang melakukan bagi gereja-Nya agar semua anggota tubuhnya berfungsi (1 Kor. 12, 14; Ef. 4:11-16; Rm. 12:3-8). ${ }^{22}$ Tanda ketiga, gereja yang bertumbuh dan sehat adalah gereja ini cukup besar dan gereja yang kecil yang anggotanya terus bertambah (Kis. 2:47), gereja yang cukup besar adalah gereja yang samasama efektif dalam melakukan penginjilan. Gereja kecil yang bertumbuh pada akhirnya menjadi gereja yang bertumbuh menjadi besar karena melakukan penginjilan yang efektif. ${ }^{23}$

Tanda keempat, gereja yang bertumbuh dan sehat adalah gereja yang memiliki rumusan: ibadah raya + jemaat + sel. Wagner mengungkapkan bahwa yang dimaksud ibadah raya adalah orang banyak berkumpul, memiliki hati yang rindu akan Allah, suatu pengalaman ibadah yang istimewa dapat terjadi. Orang banyak ini mengalami perjumpaan dengan Kristus dan Firman-Nya. Komunitas sel merupakan unsur yang penting bagi sebuah gereja yang bertumbuh dan sehat, karena melalui komunitas sel persekutuan jemaat dapat dibangun. ${ }^{24}$ Jemaat dibangun sebagai lingkungan tempat persekutuan dimana dalam komunitas sel, mereka dapat saling memperhatikan dan saling mengasihi. Tanda kelima, keanggotaannya terdiri atas golongan orang yang sama, kepentingan, kesamaan budaya, tingkat komunikasi mereka sangat cair dan adanya rasa nyaman karena seperti berada di rumah sendiri. Dalam Alkitab, sebenarnya tidaklah bertentangan, Allah yang disembah orang Kristen adalah Allah semua kaum, bahasa dan bangsa (Why. 5:9). Di dalam Kristus sudah tidak ada perbedaan tentang ras dan suku dan sebagainya (Gal. 3:28). ${ }^{25}$

Beberapa tindakan lain yang mempengaruhi pertumbuhan gereja yaitu: pertama, bertekun dalam doa. Berdoa telah diajarkan oleh para Rasul kepada jemaat mula-mula (Kis. 2:42). Berdoa juga telah diajarkan Tuhan Yesus kepada para Rasul agar mereka bertekun dalamnya (Luk. 18:1-7). Pertumbuhan gereja adalah karya Allah, karena itu, doa menjadi unsur penting dalam proses pertumbuhan gereja. ${ }^{26}$ Menurut Cho, banyak yang dapat orang percaya capai apabila mereka datang ke gereja dalam suatu sikap doa dan dengan tenang berdoa sebelum berlangsung ibadah, orang-orang berdosa telah diyakinkan oleh Roh Kudus

\footnotetext{
${ }^{21}$ Purim Marbun, "Memberdayakan Kaum Awam Bagi Pelayanan," in Empowered to Serve, ed. Junifrius Gultom (Jakarta: Bethel Press, 2015), 143-162.

${ }^{22}$ Wagner, Gereja Saudara Dapat Bertumbuh, 174.

${ }^{23}$ Ibid, 175.

${ }^{24}$ Amos Hosea, "Fenomena Kelompok Sel (Cell Group) Dalam Gereja Lokal," Diegesis: Jurnal Teologi 3, no. 2 (2018): 1-13.

${ }^{25}$ Peter Wagner, Strategi Perkembangan Gereja, 115.

${ }^{26}$ Gernaida Krisna R. Pakpahan, "Diberi Kuasa Untuk Berdoa Dengan Penuh Otoritas," in Empowered to Serve, ed. Junifrius Gultom (Jakarta: Bethel Press, 2015), 134.
} 
untuk menerima kebenaran Firman Allah. ${ }^{27}$ Kedua, penginjilan. Menurut Jenson dan Stevens penginjilan adalah sebuah proses yang terdiri atas 3 bagian, yaitu (i) proses pra-pertobatan sebagai keinsafan (Yoh. 16:7-11); (ii) proses pertobatan perpindahan dari kerajaan kegelapan ke dalam kerajaan Anak-Nya yang tunggal (Kol. 1:13); (iii) proses pasca pertobatan untuk pertumbuhan dan pendewasaan. ${ }^{28}$ Ketiga, pengajaran. Pengajaran adalah kegiatan yang berkelanjutan di jemaat mula-mula (Kis. 2:42). Orang-orang yang baru percaya harus diajar oleh para Rasul agar mereka dapat mengerti bagaimana menjadi pengikut Yesus yang benar. ${ }^{29}$ Pengajaran adalah perintah Yesus dalam Amanat Agung (Mat. 28:19-20). Jemaat yang diajarkan untuk melakukan perintah Yesus akan bertumbuh dalam kerohanian mereka.

Keempat, pemuridan. Menurut Ron dan Jim gereja telah dirancang oleh Allah dengan segala sesuatu yang diperlukan untuk memuridkan orang menjadi seperti Yesus. Pemuridan membuat setiap orang percaya dapat bertumbuh menjadi dewasa ${ }^{30}$ Kelima, persekutuan, para rasul mengajar orang percaya yang bertobat pada hari pentakosta untuk bertekun dalam pengajaran dan dalam persekutuan (Kis. 2:47). Menurut Peters, gereja merupakan sebuah persekutuan yang menyatu, berfungsi secara harmonis dan serasi, sepikir, sejiwa dan sehati, komunitas yang memiliki kebebasan, bebas berbagai kepunyaan, komunitas yang bersekutu dengan Firman, doa dan perbuatan, komunitas yang tidak membeda-bedakan. Keenam, pemimpin berhati hamba, Yesus memberikan para pemimpin gereja dalam Efesus 4:11-16 sebagai pemberian terbaik kepada jemaat dengan tujuan jemaat diajar dan diperlengkapi menjadi dewasa, bertumbuh mengenal Yesus dan berfungsi dengan baik dalam tubuh-Nya. Pemimpin yang berhati hamba dipelopori oleh Tuhan Yesus, Dia dipanggil Guru dan Tuhan, namun mencuci kaki para murid-Nya dimana mencuci kaki adalah pekerjaan para hamba (Yoh. 13:1-15). Yesus memperkenalkan sosok pribadi-Nya sebagai orang rendah hati (Mat. 11:29).

Ketujuh, visi gereja merupakan hal yang sangat penting dan berdampak nyata bagi pertumbuhan gereja. Visi melampaui waktu karena akan menggerakkan seluruh sumber daya untuk bekerja bersama-sama. ${ }^{31}$ Menurut Barna, visi akan memberikan kekuatan bagi yang memilikinya. ${ }^{32}$ Hal ini tercermin pada kehidupan Paulus seorang yang memiliki visi dari

${ }^{27}$ David Yonggi Cho, Doa: Kunci Ke Arah Kebangunan Rohani (Jakarta: Yayasan Pekabaran Injil Immanuel, 1990) 17-18.

${ }^{28}$ Ron Jenson and Jim Stevens, Dinamika Pertumbuhan Gereja (Malang: Gandum Mas, 2004), $242-$ 243. (2019).

${ }^{29}$ Amos Hosea, "Karakteristik Pendidikan Iman Dalam Pentakostalisme," Diegesis : Jurnal Teologi

${ }^{30}$ Jenson and Stevens, 211.

${ }^{31}$ Gede Widiada, "Gembala Sidang Yang Visioner," in Reaffirming Our Identity: Isu-Isu Terpilih Menjawab Perubahan Sekaligus Mempertahankan Identitas, ed. Junifrius Gultom and Frans Pantan (Jakarta: Bethel Press, 2014), 335-348.

${ }^{32}$ George Barna, Tanpa Visi Gereja Hancur (Malang: Gandum Mas, 2009), 15. 
Tuhan dan bagaimana visi itu memberi kekuatan yang hebat dalam melewati penderitaan dalam panggilannya (Kis. 9:15-16; 26:12-19). ${ }^{33}$ Alkitab mendokumentasikan bagaimana peranan Roh Kudus dalam semua rencana adanya gereja di bumi. Kisah Para Rasul menuliskan tentang kelahiran gereja dan bagaimana gereja terus bertumbuh dan berkembang tanpa batas melampaui waktu dan ruang lingkup. Peranan Allah Bapa di Surga dinyatakan oleh Yesus dalam Kisah Para Rasul 1:4-45 agar para murid jangan meninggalkan Yerusalem karena adanya sebuah janji dari Bapa yaitu tentang baptisan Roh Kudus. Pencurahan Roh Kudus di hari Pentakosta merupakan penggenapan janji Bapa di dalam Yesus, sejak Roh Kudus dicurahkan ke atas para murid, mereka menerima kuasa untuk menjalankan tugas yang Yesus amanatkan. ${ }^{34}$

Dari pemaparan di atas, penelitian ini bertujuan memaparkan bagaimana karakteristik dari gembala wanita yang ada di GBI Gloria sehingga dapat berdampak dalam pertumbuhan kuantitas dan kualitas jemaat. Penelitian ini dapat menjadi model bagi gereja-gereja yang digembalakan oleh seorang wanita untuk survive dalam segala musim pelayanan, termasuk pandemi covid-19. Penelitian terkait peran gembala wanita selama ini dilakukan dalam taraf perdebatan diperbolehkan atau tidaknya wanita untuk memimpin gereja. ${ }^{35}$ Demikian dengan pemahaman Alkitab, khususnya Perjanjian Baru yang dikaitkan dengan perkembangan masa kini. ${ }^{36}$ Secara implementatif, belum pernah dilakukan. Itu sebabnya dalam penelitian ini, peranan disoroti secara implementatif yang dapat dan telah memberikan dampak bagi pertumbuhan gereja.

\section{METODE PENELITIAN}

Penelitian ini menggunakan metode kualitatif deskriptif karena penelitian ini ingin mengeksplor mengenai karakteristik gembala wanita serta dampaknya terhadap pertumbuhan gereja, secara kualitas di GBI Gloria Tikalong. Kemudian, teknik pengumpulan data dilakukan dengan natural setting yaitu dengan pendekatan wawancara tidak terstruktur akan tetapi disiapkan secara garis besar yang akan ditanyakan. Penelitian ini mengajukan pertanyaan yang mengandung jawaban informan secara bebas. Seluruh data yang diperoleh baik lewat wawancara dan hasil catatan observasi akan disalin dengan rapi dan sistematis.

\footnotetext{
${ }^{33}$ Yusak Setianto, "Pemikiran Paulus Tentang Menghayati Hidup Kristus," in Reaffirming Our Identity: Isu-Isu Terpilih Menjawab Perubahan Sekaligus Mempertahankan Identitas, ed. Junifrius Gultom and Frans Pantan (Jakarta: Bethel Press, 2014), 371-374.

34 Junifrius Gultom, "Diberi Kuasa Menjadi Umat Allah Yang Misional," in Empowered to Serve, ed. Junifrius Gultom (Jakarta: Bethel Press, 2015); Gernaida Krisna R Pakpahan, “Jesus As the Spirit Baptizer," in Pemikiran Teolog Gereja Bethel Indonesia Tentang Teologi Pentakosta (Jakarta: Bethel Press, 2012).

${ }^{35}$ Elkana Chrisna Wijaya, "Perdebatan Peranan Wanita Dalam Organisasi Kristen: Tinjauan Terhadap Isu Kepemimpinan Kontemporer," Jurnal Teologi Injili dan Pembinaan Warga Jemaat 1, no. 2 (2017): 103117.

${ }^{36}$ Nunuk Rinukti, "Peranan Perempuan Menurut Perjanjian Baru Bagi Perkembangan Kepemimpinan Perempuan Di Dalam Gereja,” Jurnal Teruna Bhakti 1, no. 1 (2019): 33.
} 
Hasil wawancara akan dituangkan dalam bentuk verbatim dan disusun dalam bentuk table guna memudahkan, melakukan analisis dan membaca data. Peneliti akan mengklasifikasikan dan mengkategorikan data sesuai dengan pokok yang diteliti. Peneliti akan menyeleksi datadata yang benar-benar diperlukan dan mendukung topik yang akan diteliti. Data yang ditampilkan akan dianalisis kembali, dan terus melakukan seleksi guna menjaga keakuratan dengan cara adanya uji keabsahan data. Jika memungkinkan peneliti akan kembali ke lapangan untuk memperdalam lagi, apa yang masih dinilai kurang jelas. Melakukan konfirmasi ulang, melakukan penyempurnaan, dan bahkan kemungkinan data dapat berkembang. Selanjutnya proses analisis data kualitatif yang dilakukan akan bersifat sirkulasi lokasi penelitian dilaksanakan di GBI Gloria Tikalong dari sejak bulan November 2019 sampai September 2020.

\section{HASIL DAN PEMBAHASAN}

\section{Karakteristik Gembala Wanita GBI Gloria Tikalong Menuju Pertumbuhan Gereja}

\section{Pemimpin Penggembalaan}

Karakteristik utama yang ditemukan pada gembala wanita GBI Gloria Tikalong adalah kepemimpinan yang efektif dalam penggembalaan jemaat. Bertanggung jawab, mengayomi yang dipimpin untuk mencapai suatu tujuan, menjadi teladan dalam ketekunan, namun kepemimpinan wanita lebih toleransi, lebih fleksibel dan punya naluri keibuan. Menurut peneliti yang menentukan keberhasilan dalam sebuah pelayanan adalah tergantung kepada kepemimpinan, kepemimpinan menjadi kunci pembuka bagi suksesnya sebuah pelayanan. Misalnya saja, kepemimpinan Ester.

Contoh visi Gereja Bethel Indonesia secara umum adalah "Menjadi Seperti Yesus", artinya melalui pemimpin GBI pusat, pemimpin daerah, pemimpin gereja lokal dan seluruh jemaat GBI, akan menunjukkan adanya "Inkarnasi Yesus di dalam diri mereka tersebut", yaitu Yesus hidup dan berkarya melalui seluruh anggota GBI. Disini seluruh anggota GBI mentaati firman Allah serta mempermuliakan Tuhan dalam segala bidang, hidup dan kegiatannya, dan ditandai adanya transformasi hidup (perubahan hidup secara total) yang dibuktikan dengan pertobatan, pembaharuan, pemulihan hidup dan semangat kerja yang menjadi berkat.

Untuk mencapai visi ini tidak semudah menuliskannya di atas kertas, melalui berbagai tantangan, goncangan, air mata penderitaan, sampai hari ini menjalani pelayanan ini sendiri selama 16 tahun. Peneliti mempunyai tanggung jawab penuh atas pelayanan yang sudah dimulai 26 tahun yang lalu, bertanggung jawab dengan setiap jiwa, khususnya jiwa yang telah Tuhan percayakan yaitu jemaat GBI Gloria. Mereka yang sudah percaya dan dibaptis, 197 | Copyright@ 2021, CARAKA, ISSN 2722-1407 (Cetak), 2722-1393 (Online) 
seperti jawaban semua informan yaitu bahwa seorang pemimpin itu mengayomi (menggembalakan jemaatnya) agar tidak kembali lagi ke jalan yang salah, agar tidak gampang terbawa arus dunia yang akhirnya meninggalkan Tuhan dan binasa. Menurut Mazmur 23:1-6, Tuhan Yesus menyebut diri-Nya "Gembala yang baik", gembala yang baik mengajarkan halhal yang penting, gembala yang baik menjaga domba-domba dari serangan binatang buas, gembala yang baik melatih domba-dombanya supaya mematuhi perintah gembala, gembala yang baik merawat kawanan domba dengan lembut, gembala yang baik mengenal nama domba-dombanya (Yoh. 10:14,16). Gembala yang baik di pagi hari menggiring dombadombanya ke padang rumput yang hijau dan siang hari ke air yang tenang, pada saatnya para pekerja akan memangkas bulu domba, dan saat ini adalah saat yang menggembirakan setiap malam gembala menghitung dan memastikan kesehatan setiap dombanya.

\section{Pemimpin Berintegritas}

Seorang pemimpin yang baik terlihat dari integritasnya dalam kehidupan sehari-hari. Dalam hasil wawancara, informan memberikan karakteristik adil, bijaksana, tegas, disiplin, dan dapat dipercaya adalah faktor penting dalam kepemimpinan di GBI Jemaat Gloria yang terdapat pada para pemimpin wanitanya. Hal ini seperti yang diungkapkan oleh Martopan (Pendata Muda) seorang wakil gembala bersama 26 informan lainnya yang berkata bahwa karakteristik gembala wanita bagi pertumbuhan secara kualitas di GBI jemaat Gloria Tikalong adalah pemimpin yang efektif, baik pria maupun wanita adalah orang yang mempunyai visi yang jelas. Menurut $\operatorname{Alos}^{37}$ salah satu hamba Tuhan di GBI Gloria dan 24 informan yang lain, bahwa pengaruh dari kepemimpinan wanita GBI Jemaat Gloria Tikalong tercermin dari pemimpin yang menjadi teladan dalam perkataan dan perbuatan. Keteladan ini membuat informan mengalami perubahan karakter, mulai bisa menghargai pemimpin, sekarang sudah bisa membedakan mana yang baik dan mana yang jahat, mana yang berkenan kepada Tuhan dan mana yang tidak.

\section{Pemimpin Dewasa Rohani}

Karakteristik ketiga adalah dewasa rohani. Seorang yang dewasa rohani dapat dinilai dari prinsip dan sikap hidupnya dalam berhubungan dengan orang lain. Apabila dia adalah seorang yang rela berkorban, lebih memilih melayani daripada dilayani, mengasihi, selalu memperdulikan orang susah dan menginspirasi orang lain, maka pemimpin tersebut dapat dikatakan sebagai seorang yang dewasa rohani. ${ }^{38}$ Sebagai seorang pemimpin wanita, kriteria

\footnotetext{
${ }^{37}$ Seorang Pengerja GBI Jemaat Gloria, Wawancara dilakukan pada tanggal 03 Juli 2020

${ }^{38}$ Robert Paul Trisna, "Empowered for A Life Od Service: God's Calling for All Believers," in Empowered to Serve, ed. Junifrius Gultom (Jakarta: Bethel Press, 2015), 54. 
ini terlihat jelas dengan dilengkapi oleh naluri keibuan yang mudah dalam memotivasi dan memberi arahan yang baik. Pemimpin yang melayani adalah pemimpin yang rela turun ke bawah bersama orang yang dipimpinnya untuk melakukan apa yang harus dilakukannya. Pemimpin yang melayani sudah ditunjukkan oleh Tuhan Yesus sendiri dalam karya-Nya.

Bapak Itus ${ }^{39}$ bersama 25 informan lainnya kepemimpinan yang efektif adalah pemimpin yang mengabdi, dan hal ini merupakan ekspresi ketulusan hati. Lebih lanjut Bapak Itus mengatakan bahwa seorang pemimpin wanita itu adalah orang yang suka belajar, orang yang tekun dalam mengarahkan dan menjadi pelopor untuk membawa seorang mencapai keberhasilan. Kepemimpinan yang efektif adalah bagaimana ia memberi diri, mengabdikan diri, mengubah sekelilingnya dalam pengabdian yang tulus. Martopan menyatakan dari hasil wawancara $^{40}$ mengenai pengaruh kepemimpinan wanita di GBI jemaat Gloria Tikalong pertumbuhan secara kualitas di GBI Jemaat Gloria Tikalong yang dapat dirasakan adalah dalam hal keteladanan dalam perkataan dan perbuatan, suka belajar, kepedulian dengan rekan sepelayanan dan tegas, informan telah dibina (sebelum bertobat) sampai menjadi pendeta muda (Pdm). Sekarang sudah diberkati dalam keluarga dengan tiga orang anak, isteri bisa menjadi penolong, dan anak-anak dari kecil sudah hidup taat pada orang tua, dan takut akan Tuhan. Senada dengan saudari Andira Riska seorang guru PAUD dengan 20 informan melalui kepemimpinan yang suka berdoa, pemimpin yang rela berkorban dan memiliki naluri seorang ibu informan mengalami perubahan dan pertumbuhan yang besar dari seorang yang pendiam, pemalu, tertutup, mudah tersinggung, berubah total, sekarang menjadi pelayan Tuhan bergabung dengan tim musik sebagai singer di ibadah raya dan pemimpin pujian di ibadah pemuda.

Seorang pemimpin wanita tentu saja tidak otomatis bisa langsung menjadi pemimpin yang baik, pemimpin yang disukai, pemimpin yang berdampak (pemimpin yang sukses), karena sukses bisa berarti banyak hal: sebuah kenyataan, sebuah sikap, atau semacam kondisi mental pada saat mempresentasikan diri kepada dunia, sebaiknya mencoba dan memancarkan ketiga hal tersebut. Sukses bukan berarti kekayaan materi, bukan berarti lebih baik dari siapapun dalam melakukan apa yang sedang dikerjakan tetapi sukses berarti memiliki sikap nyaman, citra diri yang positif, kepastian yang absolut, benar- benar siap menyongsong segala kemungkinan serta tugas apapun. Gabungan kualitas yang akan menjadikan seseorang melakukan yang terbaik inilah yang menjadikan seorang pemimpin menjadi sukses. Perlu waktu dan usaha untuk mencapainya misalnya melalui pengalaman hidup yang takut akan

${ }^{39}$ Seorang Pengerja GBI Jemaat Gloria, Wawancara dilakukan pada tanggal 03 Juli 2020

${ }^{40}$ Seorang Pengerja GBI Jemaat Gloria, Wawancara dilakukan pada tanggal 03 Juli 2020 
Tuhan, melalui pengayoman, melalui ketekunan, melalui kesabaran, melalui kepekaan, melalui naluri seorang ibu.

Jelas terdapat kekhasan kepemimpinan wanita yang ditelusuri, yaitu ketekunan berarti rajin, keras hati, bersungguh-sungguh beberapa kata bijak mengenai kata tekun: bukan karena seseorang sangat cerdas, hanya karena tekun dalam menghadapi permasalahan lebih lama. Siapapun yang tekun akan mekar seperti bunga. Hal ini dikarenakan ada daya juang dalam mengerjakan sesuatu yang dipercayakan. Bahkan seseorang yang dianggap tidak mampu mengerjakan sesuatu atau dibawah rata-rata apabila tekun akan berhasil dan lebih dihargai apa yang dikerjakan. Prinsip ini perlu digaungkan karena di era yang serba instan saat ini, ketekunan menjadi sesuatu yang sepertinya menghabis-habiskan waktu. Oleh karenanya, ketahanan hidup penting dipahami guna melakukan ketekunan. Selanjutnya, kesabaran yang merupakan sikap diri dalam menahan emosi yang tidak baik dan menahan lidah untuk tidak mengeluh. Kesabaran menunjukan nilai hidup yang kokoh dalam masalah yang sedang dihadapi. Sabar juga sering dikaitkan dengan tingkah laku positif yang ditonjolkan oleh individu atau seseorang.

Kepekaan adalah perasaan yang keluar secara spontan dalam diri ketika melihat sesuatu yang tidak seharusnya terjadi. Dapat dikatakan sebagai tindakan awal kepekaan. Kepekaan dikaitkan dengan perasaan seseorang, itu sebabnya perempuan dianggap lebih peka daripada laki-laki. Perempuan mudah untuk ikut bersedih dengan orang lain yang sedang sedih, dan juga sebaliknya. Dalam kekristenan, melatih kepekaan dapat dilakukan dengan mendengar arahan dari Roh Kudus melalui berdoa kepada Tuhan sebagai Pribadi yang mengetahui perasaan orang lain. Naluri seorang ibu, arti kata naluri adalah dorongan hati atau nafsu yang dibawa sejak lahir ibu adalah seorang yang paling berharga di hidup kita. Sepeti halnya seorang ibu telah memberikan segalanya untuk anak-anaknya. Ibu juga rela berkorban untuk keselamatan buah hatinya. Mereka selalu membuat hari-hari anak-anaknya selalu indah dengan segala kasih sayang yang diberikan. Maka dari itu, naluri dari seorang ibu terhadap buah hatinya pasti ada di dalam jiwanya. Naluri seorang ibu terhadap buah hatinya itu sangatlah kuat. Kebanyakan, ini terjadi disaat buah hatinya merantau, meskipun tempat singgahnya sangat jauh. Semua hal itu dilakukan karena beliau sangat menyayangi buah hatinya. Ciri-ciri naluri seorang ibu adalah sebagai berikut: dapat merasakan apa yang dirasakan oleh buah hatinya, sering merasakan kegelisahan, selalu mendapat firasat sebelum sesuatu terjadi pada buah hatinya.

Mengayomi adalah sebuah tindakan yang dilakukan seseorang kepada orang lain atau suatu kelompok dengan tujuan melindungi, melayani, mendampingi, serta memberikan arahan untuk menuju hidup yang lebih baik. Secara sederhana, mengayomi dapat pula diartikan 
sebagai upaya memenuhi kebutuhan sosial seorang manusia. Kehidupan doa, bukan sekedar kewajiban anak-anak Tuhan, namun doa adalah hak setiap anak-anak Tuhan. Setiap orang percaya berhak berdoa, menyerahkan segala sesuatu yang tidak bisa ia tanggung kepada Tuhan yang dahsyat dan luar biasa dalam doa kita menerima begitu banyak kekuatan, mujizat dan pemulihan. Dalam berdoa dituntut ketaatan dalam melakukan kehendak Allah. Pemimpin wanita Kristen harus menjadi model dalam keteladanan hidup (1 Pet. 2:21).

\section{KESIMPULAN}

Karakteristik gembala wanita bagi pertumbuhan gereja secara kualitas di Gereja Bethel Indonesia Gloria Tikalong Mempawah Hulu kabupaten Landak Kalimantan Barat adalah maksimal. Hal-hal yang menjadi karakteristik gembala wanita bagi pertumbuhan gereja secara kualitas di GBI Gloria Tikalong Mempawah Hulu adalah: (1) kepemimpinan yang efektif; (2) visi pemimpin; (3) keteladanan pemimpin dalam perkataan dan perbuatan; (4) melayani dan bukan untuk dilayani; (5) naluri seorang ibu; (6) kuasa doa; (7) rela berkorban. selain faktorfaktor di atas masih ada faktor lain: (9) adil dan bijaksana; (10) tegas dan disiplin; (11) dapat dipercaya. Hal ini berarti karakteristik gembala wanita bagi pertumbuhan gereja secara kualitas di GBI Gloria Tikalong tidak ditentukan oleh satu faktor saja, karena banyak faktorfaktor yang menentukannya. Faktor-faktor pertumbuhan gereja secara kualitas di GBI Gloria Tikalong adalah: Bertekun dalam doa, penginjilan, pengajaran, pemuridan, persekutuan, pemimpin berhati bapa, visi gereja, karya Roh Kudus. Jenis pertumbuhan yang dominan di GBI Gloria adalah pertumbuhan secara kuantitas dan secara kualitas.

\section{REKOMENDASI}

Peneliti merekomendasikan untuk gereja-gereja secara umum dapat memberikan kesempatan bagi wanita untuk masuk dalam tim khusus gereja guna pertumbuhan yang signifikan. Dengan memberikan kesempatan ini, maka kaum wanita dengan ciri khas dan kelebihannya dapat menyentuh jemaat secara holistik.

\section{DAFTAR PUSTAKA}

Amos Hosea. “Karakteristik Pendidikan Iman Dalam Pentakostalisme.” Diegesis : Jurnal Teologi (2019).

B, Yosafat. Integritas Pemimpin Pastoral. Yogyakarta: ANDI Offised, 2010.

Barna, George. Tanpa Visi Gereja Hancur. Malang: Gandum Mas, 2009.

Cho, David Yonggi. Doa: Kunci Ke Arah Kebangunan Rohani. Jakarta: Yayasan Pekabaran Injil Immanuel, 1990.

Gede Widiada. “Gembala Sidang Yang Visioner.” In Reaffirming Our Identity: Isu-Isu Terpilih Menjawab Perubahan Sekaligus Mempertahankan Identitas, edited by Junifrius Gultom and Frans Pantan, 335-348. Jakarta: Bethel Press, 2014. 
Gernaida KR. Pakpahan. Jalan Sunyi Kenabian Amos: Perjuangan Menegakkan Keadilan. Jakarta: Hegel Pustaka, 2021.

Gultom, Junifrius. "Diberi Kuasa Menjadi Umat Allah Yang Misional." In Empowered to Serve, edited by Junifrius Gultom. Jakarta: Bethel Press, 2015.

Hosea, Amos. "Fenomena Kelompok Sel (Cell Group) Dalam Gereja Lokal.” Diegesis: Jurnal Teologi 3, no. 2 (2018): 1-13.

Indonesia, Departement Wanita Bethel. "Modul Wanita Cakap Berdampak." Jakarta: Gereja Bethel Indonesia, 2017.

Jenson, Ron, and Jim Stevens. Dinamika Pertumbuhan Gereja. Malang: Gandum Mas, 2004.

Marbun, Purim. "Memberdayakan Kaum Awam Bagi Pelayanan." In Empowered to Serve, edited by Junifrius Gultom, 143-162. Jakarta: Bethel Press, 2015.

Mukhlis, Maulana, and Idil Akbar. "Strengthening the Integrity of Local Leadership and Its Relevance to Run Democratic Governance." FIAT JUSTISIA:Jurnal Ilmu Hukum 11, no. 2 (2018): 109.

Pakpahan, Gernaida K.R. "Membangun Solidaritas Kemanusiaan: Kritik Nabi Amos Terhadap Praktik Pelanggaran Hak Asasi Manusia.” Manna Rafflesia 7, no. 2 (2021): 441-466.

Pakpahan, Gernaida Krisna R. "Diberi Kuasa Untuk Berdoa Dengan Penuh Otoritas.” In Empowered to Serve, edited by Junifrius Gultom. Jakarta: Bethel Press, 2015.

__. "Perempuan Dan Kerajaan Allah." In Reaffirming Our Identity: Isu-Isu Terpilih Menjawab Perubahan Sekaligus Mempertahankan Identitas, edited by Junifrius Gultom and Frans Pantan. Jakarta: Bethel Press, 2014.

Pakpahan, Gernaida Krisna R. "Jesus As the Spirit Baptizer.” In Pemikiran Teolog Gereja Bethel Indonesia Tentang Teologi Pentakosta. Jakarta: Bethel Press, 2012.

Ray.C.Stedmen. Petualangan Menjelajah Perjanjian Lama. Jakarta: Duta Harapan Dunia, 2014.

Resane, K. Thomas. "Leadership for the Church: The Shepherd Model." HTS Teologiese Studies / Theological Studies 70, no. 1 (2014).

Rinukti, Nunuk. "Peranan Perempuan Menurut Perjanjian Baru Bagi Perkembangan Kepemimpinan Perempuan Di Dalam Gereja.” Jurnal Teruna Bhakti 1, no. 1 (2019): 33.

Rupa, Calvin Sholla. "Ciri Khas Seorang Gembala Berdasarkan Perspektif 1 Petrus 5:1-4." Jurnal Jaffray 14, no. 2 (2016): 165.

Setianto, Yusak. "Pemikiran Paulus Tentang Menghayati Hidup Kristus." In Reaffirming Our Identity: Isu-Isu Terpilih Menjawab Perubahan Sekaligus Mempertahankan Identitas, edited by Junifrius Gultom and Frans Pantan. Jakarta: Bethel Press, 2014.

Sirait, Bigman. Tabloid Reformata, Ed 190. Jakarta: Yayasan pelayanan Media Antiokia, 2015.

Stanley M. Horton., Ed. "Sistematic Theology, A Pentecostal Perspective." In The Creation of the Universe and Humankind, by Timothy Munyon. Springfield: Logion Press, 1994.

Sugiyono. Metode Penelitian Kualitatif Dan R and D. Bandung: Alfabeta. Alfabeta, 2015. Sumual, Ivonne Sandra. "Perempuan Dalam Gerakan Pentakosta." In Reaffirming Our Identity: Isu-Isu Terpilih Menjawab Perubahan Sekaligus Mempertahankan Identitas, edited by Junifrius Gultom and Frans Pantan. Jakarta: Bethel Press, 2014.

—. "Potret Perempuan Gereja Dalam Berbangsa." In Bergereja Dalam Bingkai Kebangsaan. Jakarta: STT Bethel Indonesia, 2016.

Trisna, Robert Paul. "Empowered for A Life Od Service: God's Calling for All Believers." In Empowered to Serve, edited by Junifrius Gultom. Jakarta: Bethel Press, 2015.

Wagner, C Peter. Gereja Saudara Dapat Bertumbuh. Malang: Gandum Mas, 2002.

Wagner, Peter. Changing Church: How God Is Leading His Church into The Future. California: Ventura, 2014.

- Strategi Perkembangan Gereja. Malang: Gandum Mas, 2002.

Wiersbe, Warren W. Hidup Bersama Firman-Renungan Harian Pasal Demi Pasal Seluruh Alkitab. Jakarta: Renungan Harian, Yayasan Glori, 2012. 
Wijaya, Elkana Chrisna. "Perdebatan Peranan Wanita Dalam Organisasi Kristen: Tinjauan Terhadap Isu Kepemimpinan Kontemporer.” Jurnal Teologi Injili dan Pembinaan Warga Jemaat 1, no. 2 (2017): 103-117.

Wiryohadi, Yonathan. "Gereja Berbasis Visi \& Misi Kerajaan Allah.” In Reaffirming Our Identity: Isu-Isu Terpilih Menjawab Perubahan Sekaligus Mempertahankan Identitas, edited by Junifrius Gultom and Frans Pantan. Jakarta: Bethel Press, 2014.

Yohanes, Andi. Tegarnya Iman Wanita. Jakarta: ANDI Offised, 2005. 